\title{
Life Quality of Pediatric Patient with Dengue Hemorrhagic Fever (DHF) Who Received Crystalloid and Colloid Fluid Treatment in PKU Muhammadiyah Hospital Yogyakarta
}

\author{
Kualitas Hidup Pasien Anak Demam Berdarah Dengue yang Diberikan Cairan Kristaloid dan Koloid \\ di Rumah Sakit PKU Muhammadiyah Bantul Yogyakarta
}

\author{
Chotijatun Nasriyah*1, Dyah Aryani Perwitasari ${ }^{1}$, Nurcholid Umam Kurniawan ${ }^{2,3}$ \\ ${ }^{1}$ Faculty of Pharmacy, Universitas Ahmad Dahlan, Yogyakarta \\ 2 The staff of Children's Health Sciences, Faculty of Medicine, Universitas Ahmad Dahlan, Yogyakarta \\ ${ }^{3}$ KSM Child Health Sciences PKU Muhammadiyah Hospital Bantul, Yogyakarta
}

DATA OF ARTICLE:

Received: 9 Nov 2018

Reviewed: 18 Dec 2018

Revised: 24 Jun 2019

Accepted: 27 Jun 2019

*CORRESPONDENCE: 805.nasri@gmail.com

DOI:

10.18196/mm.190229

TYPE OF ARTICLE:

Research

\begin{abstract}
Dengue hemorrhagic fever (DHF) in the community can have an impact of panic, death, and reduced age of hope in the family. Research on the quality of life of DHF pediatric patient who got the treatment of crystalloid and colloid fluids has never been done before. The purpose of this study was to determine the quality of life of DHF pediatric patients who received crystalloids and colloids with PedsQL instruments. The study design was a cohort with block randomization. The inclusion criteria in this study were hospitalized DHF pediatric patients aged one month -18 years from February to May 2018. The exclusion criteria were DHF patients who came with referrals from other hospitals who had received fluid therapy. Research data include the length of stay (LOS) and quality of life score with the PedsQL questionnaire. The statistical analysis was using an independent ttest and the Mann Whitney test. The length of stay for the crystalloid group is five days longer than the colloid group, which is four days. From a total of 48 subjects studied, the score for the physical function of the crystalloid fluid group $84.54 \pm$ 9.90 was higher than the colloid group of $77.58 \pm 19.30(p=0.125)$. The emotional functions in the crystalloid group obtained a score of $81.88 \pm 12.14$ higher than the colloid group, i.e., $79.17 \pm 18.5(\mathrm{p}=0.552)$. The social function in the crystalloid group had a score of $92.08 \pm 8.84$ higher than the colloid group of $86.67 \pm 13.96$ (p $=0.232$ ). The school functions in the crystalloid group had a score of $50.42 \pm 33.68$ higher than in the colloid group of $37.92 \pm 36.62(p=0.225)$. The results of this study showed that the crystalloid group had a higher quality of life score compared to the colloid group, although it was not significant.
\end{abstract}

Keywords: Quality of Life; Pediatric; PedsQL; Crystalloid; Colloid

Abstrak: Demam berdarah dengue (DBD) di masyarakat memberi dampak kepanikan, kematian dan berkurang usia harapan. Penelitian kualitas hidup anak DBD dengan cairan kristaloid dan koloid belum pernah dilakukan.Tujuan penelitian ini untuk mengetahui kualitas hidup anak DBD yang mendapat kristaloid dan koloid dengan instrumen PedsQL. Rancangan penelitian adalah kohort, pengambilan sampel secara randomisasi blok. Kriteria inklusi adalah pasien DBD rawat inap anak umur 1 bulan-18 tahun periode Februari Mei 2018. Kriteria eksklusi adalah pasien DBD dengan rujukan dari RS lain yang sudah mendapat cairan. Data penelitian meliputi lama rawat inap dan skor kualitas hidup dengan kuesioner PedsQL. Analisis statistik menggunakan independent $t$ test dan Mann Whitney 
test. Lama rawat inap kelompok kristaloid adalah 5 hari lebih lama dibanding kelompok koloid yakni 4 hari. Dari 48 subyek yang diteliti skor fungsi fisik kelompok kristaloid $84,54 \pm 9,90$ lebih tinggi dibanding kelompok koloid $77,58 \pm 19,30$ ( $p=0,125)$. Fungsi emosi kelompok kristaloid diperoleh skor $81,88 \pm 12,14$ lebih tinggi dibanding kelompok

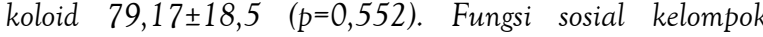
kristaloid memiliki skor 92,08 $\pm 8,84$ lebih tinggi dibanding

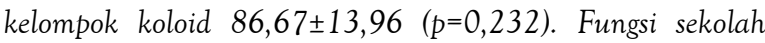
kelompok kristaloid memiliki skor 50,42 $\pm 33,68$ lebih tinggi dibanding kelompok koloid 37,92 $\pm 36,62 \quad(p=0,225)$. Hasil penelitian kelompok kristaloid skor kualitas hidupnya lebih tinggi dibanding kelompok koloid, walaupun secara statistik berbeda tidak signifikan.

Kata Kunci: Kualitas Hidup; Pediatrik; PedsQL; Kristaloid; Koloid

\section{INTRODUCTION}

The dengue hemorrhagic fever patient in Indonesia has reached the number of more than 100.000, and among them, more than 1.000 have died. ${ }^{1}$ The viral transmission of dengue hemorrhagic fever can be through the bite of an infected female mosquito. ${ }^{2}$ The impact of dengue fever in the community for now in addition to being a health problem, also causes social consequences such as panic, death, and makes the age of hope decrease in family members. ${ }^{3}$

Several attempts have been made to measure the burden of dengue fever. Long-term morbidity, mortality, and quality of life are essential metrics for measuring the health burden of chronic and acute diseases. Also, age, duration of illness, and severity of the disease were related to the quality of life of patients with dengue hemorrhagic fever. ${ }^{4}$

The most important treatment for DHF is the particular emphasis on proper and careful fluid management to overcome the plasma leak caused by the infection. ${ }^{5}$ The types of crystalloid and colloidal fluids are the choices used to replace plasma leaks. ${ }^{6}$ Liquid crystalloid properties that have components similar to blood, which do not cause allergies, are cheap, and are easily obtained making crystalloids become the therapy of choice compared to colloids. ${ }^{7}$ Also, crystalloid solutions have a molecular size smaller than colloidal solutions then, if, in the same amount of volume, there will be less crystalloid fluid that remains intravascular. ${ }^{7}$ However, colloids have advantages, namely if colloids and crystalloids have the same amount of volume, colloids have greater plasma volume (intravascular) expansion and last longer for intravascular space than crystalloid. By these advantages, it is expected that colloids provide better tissue oxygenation and hemodynamics are more stable, as a consequence, plasma leakage can be prevented and maintenance time can be reduced. ${ }^{8}$

DHF patients need intensive care at the hospital. ${ }^{9}$ Hospital care can contribute psychologycal stress on the patients especially pediatric patients because the child is separated from his parents, siblings, and friends, meets the medical staff who care for him, gets painful medical treatments, unfamiliar places, interrupts daily activities and school activities. $^{9}$

The quality of one's life is greatly influenced by physical and psychological activities. Decreasing physical function and stress can interfere with all aspects of life, one of which is the quality of life. ${ }^{10}$ Quality of life on health can be defined as a multidimensional assessment that includes physical, psychological, social functions and changes in behavior or development in one's life. ${ }^{9}$ To assess the quality of adequate intensive management of an illness, an outcome assessment is needed. This outcome assessment is not only based on mortality outcomes but also includes non-mortality assessments, such as quality of life. ${ }^{9}$ So far, researchers have not found an assessment of the quality of life in a pediatric patient with DHF who are treated with crystalloid and colloid fluids. Based on the fact mentioned before, this research is carried out.

\section{MATERIAL AND METHOD}

The study was conducted in the pediatric ward of PKU Muhammadiyah Bantul hospital in January June 2018. The design of this study was a cohort; sampling was done by block randomization. The inclusion criteria were hospitalized DHF pediatric patients aged $1-18$ years in the period February May 2018. The exclusion criteria in this study were DHF patients who came with referrals from other hospitals that had received fluids. Forty-eight samples met the inclusion criteria. The samples were divided into two groups, namely the group $(n=24)$ who received colloid fluid (initial gelafusal) and the group ( $n=24$ ) who received single crystalloid fluid therapy (ringer lactate). The application of this type of fluid is based on randomization carried out during the study. The old data from hospitalization were seen and recorded from the patient's medical record on the nurse ward.

The quality of life of pediatric patients with DHF, was measured using the PedsQL 4.0 Generic Core Scales questionnaire, which included four functions, namely physical, emotional, social, and school functions. Parents/guardians of patients before interviews and filling out the questionnaires, they need to fill out the informed consent sheet 
first as a form of approval to be the subject of research. The questionnaires were taken a day before the pediatric patients came home from the hospital. The parent/guardian of the patient is asked to fill in the form containing the patient's identity, the name of the parent/guardian, address, and signature. The assessment of the quality of life is calculated starting from physical, emotional, social, and school functions with a generic measurement scale consisting of 23 questions.

The questionnaires were asked to the parents/guardians of patients based on five scales, which were marked by the value according to the problem of each item felt by the patient. The scale consists of o never; 1 rarely; 2 sometimes; 3 often; 4 almost always. Each score received from respondents is transformed to a scale of $0-100(0=100 ; 1=$ $75 ; 2=50 ; 3=25 ; 4=0)$. The calculation of the total score of 23 question items is the average of all the number of answers to items divided by many items answered from the physical, emotional, social, and school subscales. Higher scores indicate a better quality of life.

The analysis of length of stay data and results of quality of life scores - to compare the two groups, were carried out with independent t-test and Mann Whitney test. The independent samples t-test was carried out for data that are generally distributed by showing p-value. At the same time, the Mann-Whitney test for data that is not normally distributed.

Based on the results of previous research validation, in this study, researchers also conducted validation and reliability tests related to the PedsQL questionnaire against 30 parents/guardians of pediatric patients. The validation and reliability tests apply the four functions/domains that include physical, emotional, social, and school functions using the SPSS statistical program. The results of each function/domain to test the validity obtained $r$ count value higher than $r$ table (0.361), so the questionnaire was declared valid. As for the reliability test, the correlation value in the Cronbach's Alpha column was 0.852 , which means that it is classified as very strong. Thus, it can be concluded that the questionnaire can be declared valid and trusted based on the correlation value of 0.852 .

\section{RESULT}

From a total of 48 patients who met the inclusion criteria, divided into two groups; 24 patients with cervical fluid (Ringer's lactate) and 24 patients with colloidal fluid (gelafusal).

Table 1 . The majority of the subject was 26 women patients (54.2\%) and 22 men patients (45.8\%). These two groups have similar age characteristics, i.e., the number of patients with less than or equal to 5 years are more than the number of patients over the age of 5 years.

The comparison of length of stay between the crystalloid group and the colloid group can be seen in Table 2.

The parameters of length of stay were measured using several days as long as the patient received treatment at the hospital. The group of crystalloid fluid therapy has a length of stay of 3 to 8 days with 3 patients were treated for 3 days (12,5\%), 6 patients were treated for 4 days (25\%), 6 patients were treated for 5 days (25\%), 7 patients were treated for 6 days (4,2\%), 1 patient was treated for 7 days and 1 patient was treated 8 days (4,2\%) whereas in the colloid fluid group it has a length of stay of 3 to 5 days with 5 patients were treated for 3 days $(20,8 \%), 14$ patients were treated for 4 days $(58,4 \%)$ and 5 patients were treated for 5 days (20,8\%).

Table 1. Characteristics of DHF Pediatric Patients with Crystalloid and Colloid Fluids Treatment Based on Gender and Age $(\mathrm{n}=24)$

\begin{tabular}{|c|c|c|c|c|c|}
\hline \multirow[b]{2}{*}{ Characteristics } & \multicolumn{2}{|c|}{ Type of Fluid } & \multirow[b]{2}{*}{ Total (\%) } & \multirow[b]{2}{*}{ Average \pm SD } & \multirow[b]{2}{*}{ p-value } \\
\hline & $\begin{array}{c}\text { Crystalloid } \\
n=24(\%)\end{array}$ & $\begin{array}{c}\text { Colloid } \\
\mathrm{n}=24(\%)\end{array}$ & & & \\
\hline \multicolumn{6}{|l|}{ Gender } \\
\hline Man & $6(27.3)$ & $16(72.7)$ & $22(45.8)$ & & \multirow{2}{*}{$0.564^{\mathrm{a}}$} \\
\hline Women & $18(69.2)$ & $8(30.8)$ & $26(54.2)$ & - & \\
\hline \multicolumn{6}{|l|}{ Age } \\
\hline$<1$ year & - & $1(100)$ & $1 \quad(2.0)$ & \multirow{4}{*}{$4.4 \pm 3.3$} & \multirow{4}{*}{$0.320^{\mathrm{b}}$} \\
\hline $1-5$ year & $17(48.6)$ & $18(51.4)$ & $35(72.9)$ & & \\
\hline $6-10$ year & $5(50)$ & $5(50)$ & $10(20.8)$ & & \\
\hline $11-15$ year & $2(100)$ & - & $2 \quad(4.2)$ & & \\
\hline
\end{tabular}


Table 2. Frequency of Length of Stay for Pediatric Patient with DHF between Groups of Crystalloid and Colloid Fluids

\begin{tabular}{cccc}
\hline Length of stay in inpatient centre (day) & $\begin{array}{c}\text { Group of Crystalloid } \\
\text { Fluid }(\mathbf{n}=\mathbf{2 4})\end{array}$ & $\begin{array}{c}\text { Group of Colloid Fluids } \\
(\mathbf{n}=\mathbf{2 4})\end{array}$ & $\begin{array}{c}\text { Total } \\
(\mathbf{n}=\mathbf{4 8})\end{array}$ \\
\hline 3 & $3(12.5 \%)$ & $5(20.8 \%)$ & $8(16.7 \%)$ \\
4 & $6(25.0 \%)$ & $14(58.4 \%)$ & $20(41.7 \%)$ \\
5 & $6(25.0 \%)$ & $5(20.8 \%)$ & $11(22.9 \%)$ \\
6 & $7(29.1 \%)$ & - & $7(14.6 \%)$ \\
7 & $1(4.2 \%)$ & - & $1(2.1 \%)$ \\
8 & $1(4.2 \%)$ & - & $1(2.1 \%)$ \\
Total & $24(100 \%)$ & $24(100 \%)$ & $48(100 \%)$ \\
\hline
\end{tabular}

Based on Table 3., the average length of stay for the colloid fluid group was 4 days, it's shorter than the group of patients who received crystalloid fluid, i.e. 5 days. The results of the independent analysis of the t-test in this study that there were statistically significant differences in the length of stay between the groups of crystalloid fluid and to the colloid fluid group with a value of $p=0.002$ ( $p$ $<0.05$ ).

Analysis of data related to the assessment of the life quality of children with dengue hemorrhagic fever was carried out using independent sample ttest statistics and Mann-Whitney test. The following is a table of assessment results of the quality of life between the two groups, including 4 functions/ domains.

Table 4. explains about the assessment of the quality of life of children with DHF who received crystalloid and colloid fluids. The assessment of the four functions of the crystalloid group have a higher physical function $(84,54 \pm 9,90)$ compared to the

Table 3. Results of Average Comparison Statistics of Length of Stay Patients with DHF Group of Crystalloid and Colloid Fluids

\begin{tabular}{lll}
\hline Liquid type & Mean $\pm \boldsymbol{S D}$ & p-value \\
\hline Kristaloid $(\mathrm{n}=24)$ & $5,00 \pm 1,286$ & $0,002^{\text {a* }}$ \\
Koloid $(\mathrm{n}=24)$ & $4,00 \pm 0,659$ \\
\hline \multicolumn{3}{c}{ independent t test } \\
& ${ }^{*}$ significant p value
\end{tabular}

Table 4. Statistics Results on Differences in the Life Quality in Children with DHF in the Administration of Crystalloid and Colloid Fluids

\begin{tabular}{|c|c|c|c|}
\hline \multirow{2}{*}{$\begin{array}{l}\text { Life Quality } \\
\text { Assessment }\end{array}$} & \multicolumn{2}{|c|}{ Average Value \pm SD } & \multirow[t]{2}{*}{$p$-value } \\
\hline & Crystalloid & Colloid & \\
\hline Fungsi Fisik & $84,54 \pm 9,90$ & $77,58 \pm 19,30$ & $0,125^{*}$ \\
\hline Fungsi Emosi & $81,88 \pm 12,14$ & $79,17 \pm 18,51$ & $0,552^{*}$ \\
\hline Fungsi Sosial & $92,08 \pm 8,84$ & $86,67 \pm 13,96$ & $0,232^{* *}$ \\
\hline Fungsi Sekolah & $50,42 \pm 33,68$ & $37,92 \pm 36,62$ & $0 ., 225^{*}$ \\
\hline & & & \\
\hline
\end{tabular}

colloid group $(77,58 \pm 19,30)$; emotional function of the crystalloid group $(81,88 \pm 12,14)$ was higher from the colloid group $(79,17 \pm 18,51)$; social function of crystalloid group $(92,08 \pm 8,84)$ was higher from the colloid group $(86,67 \pm 13,96)$, and school function of crystalloid group $(50,42 \pm 33,68)$ was higher from the colloid group $(37,92 \pm 36,62)$.

\section{DISCUSSION}

The number of patients with dengue hemorrhagic fever (DHF) in Table 1. shows that the majority of DHF patients are women, as many as 26 patients $(54,2 \%)$, while male patients were 22 patients (45,8\%). Another study conducted by Hukom (2013), ${ }^{11}$ also showed more women than men with a percentage of $53.2 \%$.

From the results of this study, the age was dominated between 1-5 years, with a total of 35 patients $(72,9 \%)$ from a total of 48 samples. The result was that both women and men under the age of 5 have a greater risk of getting a virus than children over 5 years because children under 5 years have a lower level of immunity. ${ }^{12}$ According to the results of research conducted by Muliansyah (2015), ${ }^{13}$ the majority of patients with dengue hemorrhagic fever were under 15 years old with 44 people (90\%). Other research in India by Saraswathy (2013), ${ }^{14}$ showed the majority of patients with dengue hemorrhagic fever aged 1-5 years (57\%), followed by children aged 6-12 years (29\%).

Table 3 . shows the results of the mean statistic of the length of stay showed significant differences with values $(p=0,02)$. The duration of stay in the crystalloid group was 5 days, longer than the length of stay in the colloid group, which was 4 days. These results were in accordance with the theory that colloidal fluids have the advantage that in the same amount of volume there will be greater plasma volume expansion (intravascular) and last for a long time in the intravascular space compared to crystalloid. With these advantages, it is expected that colloids provide better tissue oxygenation and maintain more stable hemodynamics so that they 
can prevent plasma leakage and reduce maintenance time. ${ }^{8}$

Based on the previous PedsQL research, good score for healthy children were around 83 with the lowest score of 70 , while for children with disease the score was between 60 and less than $70 .{ }^{15}$ According to the survey results of the PedsQL instrument maker, the average results of the total scores for children with healthy conditions were $81.38 \pm 15.90$. Quality of life can be declared normal according to the survey if the total value is more than 65.48 and vice versa has a quality of life of "atrisk" if the total value is less than $65.48 .{ }^{15}$

In the average study of the quality of life quality between crystalloid and colloid groups (table 4), each physical function, emotional function and social function show the results $\geq 65.48$ which means that the three functions/domains are declared normal. In accordance with a research by Thompson and Vernon (1992) cited by Aji (2004), 9 menyatakan bahwa Post-treatment physical and psychological problems are more often happen in length of stay for more than 2 weeks, repeated care, and sufferers of chronic diseases. In this study, the duration of the length of stay in DHF children was less than 2 weeks, and the underlying disease is an acute infectious disease so that the results of normal quality of life are still obtained.

School function for crystalloid and colloidal groups showed the results of $<65,48$, which means both groups are still declared below normal/risky. In line with several studies, one of them was conducted by Dwi, Krisna and Nur (2016), ${ }^{16}$ ho explained that physical and school scores in cancer children were significantly lower than healthy children. This was due to conditions that had to be hospitalized in the hospital, giving rise to high absenteeism rates from school.

From the assessment of the life quality of DHF children, the crystalloid group has a higher score than the colloid group. It is because the majority of the age in the colloid group is less than 5 years. In line with the research by Thomson dan Vernon (1992), ${ }^{9}$ who viewed from the psychological point of view of post-hospital care children stated that emotional disorders most often occur in children aged 6 months to 6 years. The research by Evy (2017), ${ }^{17}$ also said that children aged 9-12 years have more mature cognitive development than those below them so that positive self-concepts can be formed. This study expects information or communication by health workers to prevent or control dengue fever especially during the peak season, and for health services to consider using colloid fluids as initial treatment for DHF to reduce the length of stay.

\section{CONCLUSION}

The result of the assessment related to the life quality of children with dengue hemorrhagic fever is that the crystalloid group had a higher score than the colloid group, though statistically, the differences were not significant. All authors declare that there is no potential conflict of interest with research, authorship and or publication of this article.

\section{REFERENCE}

1. Kemenkes RI. Pusat Data dan Informasi Situasi DBD. Pusdatin. Jakarta: Kemenkes RI. 2016.

2. Bruce R. Dengue Fever/Dengue Hemorrhagic Fever. Am J Med, 2010; 7 (2): 51-53.

3. Kemenkes RI. Demam Berdarah Dengue (DBD). Jakarta: Kemenkes RI. 2017 Apr 25. From: www.kemkes.go.id

4. Bach X, Giang T, Long H, Anh T, Tung T, Binh $\mathrm{T}$, et al. Cost-of-Illness and the Health-Related Quality of Life of Patients in the Dengue Fever Outbreak in Hanoi in 2017. Int J Environ, 2018; 15 (6): 1174 .

5. Cucunawangsih \& Nata PHL. Trends of Dengue Disease Epidemiology. Virology (Auckl), 2017; 8: 1. 6.

6. Hung N. Fluid Management for Dengue in Children. Paediatr Int Child Health, 2012; 32 (Suppl 1): 39-42.

7. Lisa S. Choosing between Colloids and Crystalloids for IV Infusion. Nursing Times, 2017; 113: 12, 20-23.

8. Antonios L. Volume Resuscitation; the Crystalloid Vs Colloid Debate Revisited. Medscape, 2004; Available

from:URL:http://www.medscape.com/viewarticle $/ 480288$

9. Fajar A. Kualitas Hidup Anak Pasca Sindrom Syok Dengue [tesis]. Semarang: Fakultas Kedokteran Universitas Diponegoro. 2004.

10. Hsien T, Li-Min Wu, Shu-Hui Wen. Quality of Life and Its Predictors Among Children and Adolescents with Cancer. Cancer Nursing, 2017; 40 (5): 343-351.

11. Andrew H, Sarah M, Maya M. Hubungan Nilai Hematokrit dan Jumlah Nilai Trombosit pada Pasien Demam Berdarah Dengue. Jurnal e-Biomedik (eBM), 2013; 1 (1): 707-711.

12. Devi Y, Galuh R, Andra N. Hubungan Status Gizi, Umur dan Jenis Kelamin dengan Derajat Infeksi Dengue pada Anak. Jurnal Kedokteran Muhammadiyah, 2015; 2(1): 24-28.

13. Muliansyah, Tri B. Analisa Pola Sebaran Demam Berdarah Dengue terhadap Penggunaan Lahan 
dengan Pendekatan Spasial di Kabupaten Banggai Provinsi Sulawesi Tengah Tahun 2011-2013. Journal of Information System for Public Health, 2016; 1(1): 47-54.

14. Saraswathy M, Sankari K, Sakthi G, Sripriya D, Lakshmi P. Incidence of Dengue Hemorraghic Fever in Children: A Report From Melmaruvathur Tamilnadu India. JPSI, 2013; 2 (1): 34-36.

15. Skar D, Varni JW, Seid M, Burwinkle TS. Health Status Assesment Project. Data Insight Report
Children's Health Assessment Project, 2002; 10: 1 11.

16. Dwi N, Krisna Y, Nur A. Faktor-faktor Berhubungan dengan Kualitas Hidup Anak Leukemia Limfositik Akut yang Menjalani Kemoterapi. JKP, 2016; 4 (1): 5-7.

17. Evy S, Livana P, yulia S. Hubungan Konsep Diri dengan Kualitas Hidup Anak Usia Sekolah pada Keluarga Buruh Migran Internasional. IJHS, 2017; 1 (2): 21-28. 